\title{
CHARACTERISTIC OF BIO-GEOMETRIC PROFILE OF STUDENTS' POSTURE AND PHYSICAL FITNESS IN PROCESS OF PHYSICAL EDUCATION
}

Dudko M.V.

Kyiv National Economic University named after Vadym Hetman

\begin{abstract}
Purpose: to determine specific features of bio-geometric profile of posture and physical fitness of students in process of physical education. Material: 250 students were tested. Video-recording and analysis of bio-geometric profile of human posture were fulfilled. Program Torso was used for this purpose. Results: it was found out that only $15.2 \%$ of students had correct posture. The most quantity of posture abnormalities was detected in $36.4 \%$ of the tested. In sagittal plane we observed the following types of abnormalities: round back - in $24.4 \%$ of students, slouching back in $24 \%$ of students. We found that $63.3 \%$ of students with normal posture are in zone of risk. Low backbone flexibility, mobility of hip joints and elasticity of hamstrings was detected on students. Conclusions: students with unsatisfactory bio-geometric profile of posture (scoliosis posture - 43.33\%; round back - 23. 33\%; slouching back - 22. $73 \%$ ) are in the called pre-morbid state of muscular-skeletal apparatus.
\end{abstract}

Key words: students, physical education, posture, visual screening.

\section{Introduction}

In modern conditions, educational process in higher educational establishments is connected with continuously increasing informational flow and with significant psychological loads. It sets high requirements to students' health condition and physical fitness that is important condition of ensuring of students' harmonious development. [13, 20, $23]$.

Most of specialists $[1,3,7,8]$ connect it with unfavorable social economic conditions of life and ecology, with substantial reduction of students' interest to physical culture and sports, weakening of physical education system in higher educational establishments.

Numerous researches $[2,4,10,17-19,22]$ witness that mass character of posture abnormalities - is one of the most pressing problems of modern society. Functional abnormalities of posture are one of the most wide-spread deviations in muscular skeletal system of modern students [8, 9, 24]. Postures disorders negatively influence on function of internal organs, cardio-vascular, respiratory and digestive systems. They negatively impact on human mental; and physical workability [1, 3, 8, 9, 25-30].

At present time there is great number of scientific publications $[4,5,6,7,13,21]$ on studying of posture abnormalities of students and approaches to their correction by physical education means. However, some problems have still been remaining unsolved.

In our opinion, for effective planning of health related work it is purposeful to use "screening" [10]. Its purpose is to detect students with "risk zones" of posture's bio-geometric abnormalities as well as determination of pre-morbid states of muscular-skeletal apparatus (MSA).

Generalizing specialists' views we can state the fact that correction of posture's bio-geometrical profile abnormalities of students is reflected in many publications. At the same time some questions, concerning prophylaxis of such abnormalities have not been profoundly worked out yet.

Purpose, tasks of the work, material and methods

The purpose of the work is to determine specific features of bio-geometric profile of posture and physical fitness of students in process of physical education.

The tasks of he work:

1. To generalize scientific data on prophylaxis and correction of students postures' abnormalities by means of physical education, by data of special literature.

2. To determine the most frequent abnormalities of posture's bio-geometrical profile, level of its state and specificities of students' physical fitness.

The methods of the research: we used the following methods: theoretical analysis and generalization of special scientific-methodic literature, pedagogic observations, pedagogic testing, anthropometry, video recording and analysis

(C) Dudko M.V., 2015

http://dx.doi.org/10.15561/20755279.2015.0402 
of human posture's bio-geometrical profile with the help of program "Torso", visual screening", methods of mathematical statistic. In the research 250 first year students of Kyiv National Economic University named after Vadym Hetman participated.

\section{Results of the research}

Collection of data from students' medical records was conducted with direct participation of vertebraneurology specialist. Visual screening and application of "Torso" program [9] permitted to detect that only $15.2 \%$ of students have normal posture. Types of posture's abnormalities were distributed in the following way: scoliosis posture $36.4 \%$ of the tested, slouching back $24 \%$, round back $-24.4 \%$ of students.

To receive urgent information about bio-geometrical profile of students' postures it is necessary to have simple informative indicators. These indicators shall be easily accessible to physical culture teacher; not require diagnostic apparatuses and great time losses. In our case we used improved record of control over posture's bio-geometric profile [7].

For assessment of posture's bio-geometric profile we used the following indicators:

- In respect to sagittal plane - position of head and torso in respect to vertical axis, chest kyphosis and lumbar lordosis, shape of abdomen, angle between hip and shin;

- In respect to frontal plane - position of head in respect to horizontal axis, location of shoulders, of blades lower angles and pelvis bones, triangles of waist, position of feet.

Every indicator was assessed by three points' scale. We used method of comparison of individual posture on photograph and graphic pictures of variants on sample. "Point" 1 corresponded to mark "bad", "2" - "satisfactory, "3" "good".

All 250 students were tested by map of visual screening of posture's bio-geometrical profile. It permitted to distribute students by levels, separately for every kind of posture: "low", "middle", "high" (see table 1).

Table 1

Distribution of students by state of posture's bio-geometrical profile, \%

\begin{tabular}{|c|c|c|c|}
\hline \multirow{2}{*}{ Type of posture } & \multicolumn{3}{|c|}{ Level of bio geometrical profile state } \\
\cline { 2 - 4 } & low & middle & high \\
\hline Normal posture & 0 & 63.33 & 36.67 \\
\hline Scoliosis posture & 43.33 & 56.33 & 0 \\
\hline Round back & 23.33 & 76.67 & 0 \\
\hline Slouching back & 22.73 & 77.27 & 0 \\
\hline
\end{tabular}

For determination of "risk zones" of functional disorders in muscular skeletal apparatus (MSA) orthopedist assessed students' posture in frontal and sagittal planes. We used map of express control of posture's bio-geometrical profile (norm -2 points, pathologies -1 point). All students were divided into two groups: with normal posture and with posture abnormalities. For determination of "risk zones" of MSA functional disorders we constructed graphs of normal distribution of generalized summarized points of students with normal postures and students with posture abnormalities. Sections of graphs overlapping were classified as "risk zones" (see table 2). 
Determination of level of bio-geometrical profile's state and "risk zones" by integral mark of 17-18 years' age students, points

\begin{tabular}{|c|c|c|c|c|}
\hline Age, years & \multicolumn{3}{|c|}{ Level } & \multirow{2}{*}{ Risk zone } \\
\hline & Low & Middle & High & \\
\hline 17 & $11-17$ & $18-23$ & $24-33$ & $18-20$ \\
\hline 18 & $11-16$ & $17-23$ & $24-33$ & $17-20$ \\
\hline
\end{tabular}

Analyzing the received data we can conclude that $63.33 \%$ of students with normal posture are in "risk zone". It means that these tested require deepened control of bio-geometric profile of posture. They need in prevention prophylaxis of MSA disorders.

Students with different kinds of posture abnormalities and low bio-geometrical profile level are in the so-called pre-morbid state of MSA. Pre-morbid state (from Latin prae - pre and morbus disease) is an initial human state before disease. This state is characterized by reduction of organism's adaptation potential. It has 2 stages of progressing: with prevailing of non-specific changes and preservation of homeostatic characteristics; with prevailing of specific changes in organs and systems (pathology is still not expressed and changes are of compensatory character).

Thus, slouching and round back - are types of posture, which are favorable ground for progressing of pathological kyphosis, while scoliosis posture can result in scoliosis.

At the next stage of our researches we studied physical fitness of students with different types of posture (see table 3).

It was found that students with normal posture have middle level of general endurance $2567.11 \mathrm{~m}(\mathrm{~S}=317.99 \mathrm{~m})$. It should also be noted that students with scoliosis posture and slouching back also have middle level of general endurance- $2467.58 \mathrm{~m}(\mathrm{~S}=357.18 \mathrm{~m})$ and $2440.83 \mathrm{~m}(\mathrm{~S}=283.51 \mathrm{~m})$. But these indicators have statistically significant distinctions $(\mathrm{p}<0.05)$. At the same time students with round back demonstrated the worst result $2359.02 \mathrm{~m}(\mathrm{~S}=361.42$ $\mathrm{m})$. It corresponds to the lowest level of general endurance $(\mathrm{p}<0.05)$, comparing with students with normal posture.

Testing resulted in statistically significant distinctions in indicators of students with normal posture $(9.58 \mathrm{~s}$., $\mathrm{S}=0.59)$ and students with round back $(10.05 \mathrm{~s} ., \mathrm{S}=0.48)(\mathrm{p}<0.05)$. At the same time students with scoliosis back showed middle level of dexterity ( $9.77 \mathrm{~s} ., \mathrm{S}=0.63$ and $9.71 \mathrm{~s}$., $\mathrm{S}=0.63)$. It should also be noted that these values did not statistically confidently differ from indicators of students with normal posture ( $p>0.05)$.

Table 3

Physical fitness indicators of students with different posture abnormalities $(n=250)$

\begin{tabular}{|l|c|c|c|c|c|c|c|c|}
\hline \multirow{2}{*}{ Description of test } & \multicolumn{7}{c|}{ Posture type } \\
\cline { 2 - 10 } & \multicolumn{2}{|c|}{$\begin{array}{c}\text { Normal posture } \\
(\mathrm{n}=38)\end{array}$} & \multicolumn{2}{c|}{$\begin{array}{c}\text { Scoliosis posture } \\
(\mathrm{n}=91)\end{array}$} & $\begin{array}{c}\text { Round back } \\
(\mathrm{n}=61)\end{array}$ & \multicolumn{2}{c|}{$\begin{array}{c}\text { Slouching back } \\
(\mathrm{n}=60)\end{array}$} \\
\cline { 2 - 11 } & $\bar{x}$ & $\mathrm{~S}$ & $\bar{x}$ & $\mathrm{~S}$ & $\bar{x}$ & $\mathrm{~S}$ & $\bar{x}$ & $\mathrm{~S}$ \\
\hline 12 minutes Cooper's test of walk and run, & 256711 & 317.99 & $2467.58^{*}$ & 357.18 & $2359.02 * 361.42$ & $2440.83 *$ & 283.51 \\
\hline Shuttle run «4 x 9», multiple passing of & 9.58 & 0.59 & 10.01 & 0.59 & $10.05^{*}$ & 0.48 & 10.0 & 0.72 \\
\hline one and the same distance, sec. & & & & & & & & \\
\hline
\end{tabular}




\begin{tabular}{|c|c|c|c|c|c|c|c|c|}
\hline $\begin{array}{l}\text { Initial position (i.p.): hanging with seizing } \\
\text { from above, legs are closed; chin ups } \\
\text { above bar, quantity of times }\end{array}$ & 15.11 & 2.26 & $13.35^{*}$ & 2.00 & $10.30^{*}$ & 1.54 & $12.18^{*}$ & 1.82 \\
\hline $\begin{array}{l}\text { I.p.: lying on back with legs bent in knees } \\
\text { and arms behind head. Rising in sitting } \\
\text { position, quantity of times per } 1 \text { minute. }\end{array}$ & 50.08 & 5.46 & $45.03 *$ & 7.23 & $37.92 *$ & 3.02 & $41.32 *$ & 6.09 \\
\hline $\begin{array}{l}\text { I.p. - sitting position. Maximally bend } \\
\text { forward with arms stretched also } \\
\text { forward, cm }\end{array}$ & 3.53 & 0.67 & 3.31 & 0.56 & $2.21^{*}$ & 0.33 & 3.32 & 0.41 \\
\hline $\begin{array}{l}\text { I.p. lying on abdomen with arms behind } \\
\text { head. Rising and keeping of shoulder } \\
\text { girdle, sec. }\end{array}$ & 90.08 & 9.04 & $60.71 *$ & 10.88 & $50.80^{*}$ & 3.45 & $58.77 *$ & 11.16 \\
\hline
\end{tabular}

Notes: ${ }^{*}-\mathrm{p}<0.05$ in comparison with indicators of students with normal postures.

\section{Discussion}

Results of our researches supplemented the data of other specialists [7, 13, 21, 24]. Besides, they confirmed the conception of V.A. Kashuba et al. [4-6] about prophylaxis approaches to students' physical education.

The received data witness that indicators of dynamic power endurance of shoulder girdle and back muscles of students with normal posture correspond to level above middle (15.11 times, $S=2.26$ ). It is statistically confidently higher than in students with round back ( 10.30 times, $\mathrm{S}=1.54$; level below middle) and students with scoliosis posture (13.35 times, $\mathrm{S}=2$ ). Power endurance of shoulder girdle and back muscles of students with round back and scoliosis posture corresponded to middle level $(\mathrm{p}<0.05)$.

Statistically confident differences between static power endurance of students with normal posture $(90.08 \mathrm{~s}$., $\mathrm{S}=9.04)$, scoliosis posture (60.71 s., $\mathrm{S}=10.88)$, round back (50.80 s., $\mathrm{S}=3.45)$ and slouching back (58.77 s.., $\mathrm{S}=11.16)$ $(\mathrm{p}<0.05)$ are rather substantial.

For assessment of backbone flexibility, hip joints' mobility and elasticity of hamstrings we used test "bending of torso from sitting position". Analysis of this test's results showed low level of this indicator in students with all types of posture. For example in students with normal posture this indicator was, in average, $3.53 \mathrm{~cm}(\mathrm{~S}=0.67)$, with scoliosis posture $-3.31 \mathrm{~cm}(\mathrm{~S}=0.56)$, with slouching back $-3.32 \mathrm{~cm}(\mathrm{~S}=0.41)$. With it, it should be noted that these indicators had no statistically significant distinctions $(\mathrm{p}>0.05)$. At the same time students with round back showed the lowest result $2.21 \mathrm{~cm}(\mathrm{~S}=0.33 \mathrm{~cm})(\mathrm{p}<0.05)$.

\section{Conclusions:}

1. Recent decade in Ukraine there have been observed reduction of students' health that is conditioned by a number of objective and subjective reasons: low social-economical level of life of most of students; conditions of educational functioning; deficit of students motor functioning. As a result - increase of students with functional disorders of muscular skeletal apparatus.

2. We have determined the types of posture abnormalities of students: scoliosis posture was registered in $36.4 \%$ of the tested; slouching back $-24 \%$ of students; round back $-24.4 \%$. Also attracts attention the fact that only $15.2 \%$ of students have normal posture. Increasing of quantity of students with functional disorders of muscular skeletal apparatus creates a problem situation. This potentially unfavorable state earlier or later inevitably results in weakening of organism's functional potentials. 
3. Express control of bio-geometric profile of students (5 indicators in frontal and 6 indicators in sagittal planes) points at the fact that $63.33 \%$ of the tested with normal posture have middle level of posture state. They are in the so-called "risk zone". In the future they can have functional disorders of muscular skeletal apparatus. It should also be noted that students with low level of posture's bio-geometrical profile (scoliosis posture $-43.33 \%$; round back- 23 . $33 \%$; slouching back- $22.73 \%$ ) are in the so-called pre-morbid state of MSA.

4. We detected low flexibility of backbone, mobility of hip joints and elasticity of hamstrings. Students with normal posture had this indicator, equal, in average, to $3.61 \mathrm{~cm}(\mathrm{~S}=4.18)$, students with slouching back $-2.77 \mathrm{~cm}$ $(\mathrm{S}=2.81)$, with round back $-2.21 \mathrm{~cm}(\mathrm{~S}=1.43)$; students with scoliosis posture had $2.19 \mathrm{~cm}(\mathrm{~S}=2.55)$. With it, it should be noted that the above mentioned indicators had no statistically significant distinctions $(\mathrm{p}>0.05)$.

5. Indicators of dynamic power endurance of shoulder girdle and back muscles of students with normal posture correspond to above middle level and are 15.11 times, $(S=3.94)$. It is statistically confidently higher than indicators of students with round back (10.30 times, $\mathrm{S}=2.40$; - level below middle); students with scoliosis posture (13.35 times, $\mathrm{S}=4.49$ ) and round back (12.18 times, $\mathrm{S}=3.82)$. It is very important that with registration of static power endurance statistically confident distinctions were found in students with scoliosis posture $(60.71 \mathrm{sec}$., $\mathrm{S}=10.88)$, round back (50.80 sec., $\mathrm{S}=3.45)$, slouching back (58.77 sec., $\mathrm{S}=11.16)$ in comparison with students with normal posture (90.08 sec., $\mathrm{S}=9.04)(\mathrm{p}<0.05)$.

The prospects of further researches are connected with working out of technology of not fixed MSA disorders' prophylaxis in students, in process of their physical education.

\section{Conflict of interests}

The author declares that there is no conflict of interests.

\section{References}

1. Belikova ZhA. Uprazhneniia khatkha-jogi kak sredstvo korrekcii deformacii pozvonochnika studentov special'nykh medicinskikh grupp s narusheniiami osanki. Cand. Diss. [Hatha yoga exercises as mean of backbone deformation's correction of special health groups' students with posture abnormalities. Cand. Diss.], Belgorod, 2012. (in Russian)

2. Zabalueva TV. Pedagogicheskie aspekty formirovaniia vozrastnoj osanki cheloveka [Pedagogic aspects of formation of human age posture]. Uchenye zapiski universiteta imeni P.F. Lesgafta, 2009;5:27 - 31. (in Russian)

3. Isaeva OV. Differencirovannye podkhody $k$ ozdorovleniiu studentov 16-17 let $s$ narusheniiami osanki $v$ processe fizicheskogo vospitaniia. Cand. Diss. [Differentiated approaches to health improvement of 16-17 years' age students with posture abnormalities in process of physical education. Cand. Diss.], Ivanovo, 2015. (in Russian)

4. Kashuba VA, Bibik R, Nosova N. Kontrol' sostoianiia prostranstvennoj organizacii tela cheloveka v processe fizicheskogo vospitaniia [Control of human body space organization in process of physical education]. Molodizhnij naukovij visnik Volins'kogo nacional'nogo universitetu imeni Lesi Ukrainki. 2012;7:10-19. (in Russian)

5. Kashuba VA, Dudko MV. Sovremennye podkhody, metodiki i tekhnologii k formirovaniiu zdorovogo obraza zhizni studentov $\mathrm{v}$ processe fizicheskogo vospitaniia [Modern approaches to, methodic and technologies of students' healthy life style formation in process of physical education]. Fizichne vikhovannia, sport $i$ kul'tura zdorov'ia u suchasnomu suspil'stvi. 2015;1:52 - 57. (in Russian)

6. Kashuba VA, Martyniuk OA. K voprosu ispol'zovaniia korekcionno-profilakticheskikh programm v processe fizicheskogo vospitaniia studentok s razlichnymi narusheniiami prostranstvennoj organizacii tela [On the question of usage of correction-prevention programs in physical education of girl students with different disorders of body space organization]. Naukovij chasopis NPU im. M.P. Dragomanova, 2013;1(27):28-35. (in Russian)

7. Kashuba VA, Ivchatova T, Sergienko K. K voprosu izmeneniia prostranstvennoj organizacii tela cheloveka v processe fizicheskogo vospitaniia s ispol'zovaniem komp'iuternykh tekhnologij [On the question of change of human body space organization in physical education with the help of computer technologies]. Sportivnij visnik Pridniprov'ia. 2014;1:42-45. (in Russian)

8. Kolos MA. Korekciia funkcional'nikh porushen' oporno-rukhovogo aparatu studentov v procesi fizichnogo 
vikhovannia. Cand. Diss. [Correction of functional disorders of students' muscular skeletal apparatus in process of physical education. Cand. Diss.], Dnipropenrovsk, 2010. (in Ukrainian)

9. Martyniuk OA. Korrekciia narushenij prostranstvennoj organizacii tela studentok v processe fizicheskogo vospitaniia. Cand. Diss. [Correction of disorders of girl students' body space organization in process of physical education. Cand. Diss.], Kiev, 2011. (in Russian)

10. Nosova NL. Kontrol' prostorovoi organizacii tila shkoliariv u procesi fizichnogo vikhovannia. Cand. Diss. [Control of schoolchildren's body space organization in process of physical education. Cand. Diss.], Kiev, 2008. (in Ukrainian)

11. Retivykh IuI. Metodika korrekcii narushenij osanki studentov sredstvami ozdorovitel'noj fizicheskoj kul'tury na osnove ucheta vidov i stepeni deformacij pozvonochnika. Cand. Diss. [Methodic of correction of students' postures by means of health related physical culture on the base of registration of kinds and degree of backbone deformation. Cand. Diss.], Volgograd, 2009. (in Russian)

12. Temchenko VA, Burko VL, Konik GA. Organizaciia upravleniia fizicheskoj kul'turoj i sportom v vysshem uchebnom zavedenii [Organization of management of physical culture and sports in higher educational establishment]. II regional'na naukova konferenciia "Strategichne upravlinnia rozvitkom galuzi Fizichna kul'tura i sport", 14 grudnia 2013 r., Kharkiv [II regional scientific conference "Strategic management of development of Physical culture and sports' branch". December 14th, 2013, Kharkiv], Kharkiv, HDAFK; 2014. p. 16-18. (in Russian)

13. Futornyj SM. Zdorov'esberegaiushchie tekhnologii v processe fizicheskogo vospitaniia studencheskoj molodezhi [Health related technologies in process of physical education of students], Kiev: Poligrafservis, 2014. (in Russian)

14. Erdenko DV. Metodika ispol'zovaniia vostochnoj gimnastiki pri narusheniiakh osanki studentok gumanitarnykh vuzov. Cand. Diss. [Methodic of application of oriental gymnastic with posture's abnormalities of humanitarian HEEs' girl students. Cand. Diss], Moscow, 2009. (in Russian)

15. Iumasheva LI. Korekciia porushen' postavi studentiv muzichnogo vishchogo navchal'nogo zakladu u procesi fizichnogo vikhovannia. Cand. Diss. [Posture's corrections of musical higher educational establishment's students in process of physical education. Cand. Diss], Kiev, 2007. (in Ukrainian)

16. Iakovenko DV. Ozdorovitel'naia fizicheskaia kul'tura studentov s osteokhondrozom pozvonochnika na osnove kompleksnykh korrigiruiushchikh vozdejstvij. Cand. Diss. [Health related physical culture of students with backbone osteochondrosis on the base of complex correcting impacts. Cand. Diss.], Sankt Petersburg, 2009. (in Russian)

17. AbouHassan J, Milosavljevic S, Carman A. Can postural modification reduce kinetic and kinematic loading during the bowing postures of Islamic prayer? Ergonomics. 2010;53(12):1446-1454.

18. Andrejeva Julija, Mockiene Asta, Zukauskiene Milda. Fatigue and faulty posture connection among children, diagnosed with dysarthria. Pedagogics, psychology, medical-biological problems of physical training and sports. 2015;8:75-81. http://dx.doi.org/10.15561/18189172.2015.0810

19. Andrews DM, Fiedler KM, Weir PL, Callaghan JP. The effect of posture category salience on decision times and errors when using observation-based posture assessment methods. Ergonomics. 2012;55(12):1548-58.

20. Boak A, Hamilton HA, Adlaf EM, Beitchman JH, Wolfe D, Mann RE. The mental health and well-being of Ontario students. CAMH Research Document. 2014;38:213-244.

21. Bothmer M, Fridlund B. Gender differences in health habits and in motivation for a healthy lifestyle among Swedish university students. Nursing and Health Sciences. 2005;7:107-110.

22. Cavalheri V, Camillo CA, Brunetto AF, Probst VS, Cipulo Ramos EM, Pitta F. Effects of arm bracing posture on respiratory muscle strength and pulmonary function in patients with chronic obstructive pulmonary disease. Revista Portuguesa de Pneumologia (English Edition). 2010;16(6):887-91.

23. Futornyi S. Actual issues of improving the process of student's physical education through the application of modern health-saving technologies. Molodizhnij naukovij visnik nacional'nogo universitetu imeni Lesi Ukrainki. 2014;14:26-30. 
24. Gorelov A.A., Kondakov V.L., Belikova Zh.A. About necessity of use of Hatha Yoga exercises for correction of deformation of students' spine of special medical groups with violations of posture. Physical education of students, 2013, vol.2, pp. 35-44. http://dx.doi.org/10.6084/m9.figshare. 156378

25. Hong Y, Fong DT-P, Li JX. The effect of school bag design and load on spinal posture during stair use by children. Ergonomics. 2011;54(12):1207-13.

26. Kalinichenko IO, Dyachenko YL. State changes in posture and arch of the foot in children aged $4-6$ years with hypermobility of the joints under the influence of rehabilitation activities in schools. Pedagogics, psychology, medical-biological problems of physical training and sports, 2013;8:26-30. http://dx.doi.org/10.6084/m9.figshare.745781

27. Litvinenko Y.V., Niznikowski Tomasz, Boloban V.N. Evaluation of the kinematic structure of indicators key elements of sports equipment exercise by postural orientation movements. Physical education of students, 2014;6:29-36. http://dx.doi.org/10.15561/20755279.2014.0606

28. Mani R, Milosavljevic S, Sullivan SJ. Control of posture during tasks representing common work-related postures - a reliability study. Ergonomics. 2015;3;58(6):980-989.

29. Torlakovic A, Muftic M, Radjo I, Talovic M, Mahmutovic I. Evolution of Sports-medical Team Management in the Program of Posture Correction in Children. Materia Socio Medica. 2014;26(2):104.

30. Źukowska Hanna, Szark-Eckardt Mirosława, Muszkieta Radosław, Iermakova TS. Characteristics of body posture in the sagittal plane and fitness of first-form pupils from rural areas. Pedagogics, psychology, medicalbiological problems of physical training and sports, 2014;7:50-60. http://dx.doi.org/10.6084/m9.figshare.1015583

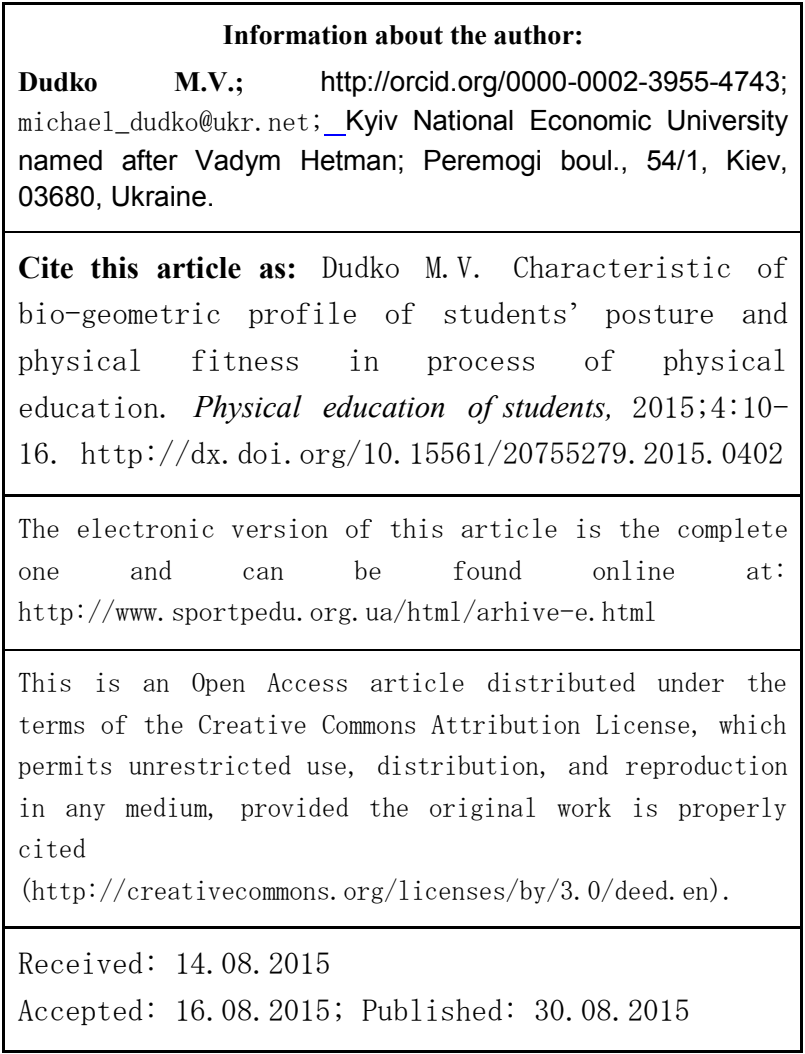

